\title{
CHARACTERIZATION OF WETLAND SOILS DEVELOPED ON LIMESTONES PARENT MATERIAL IN CROSS RIVER STATE, SOUTH EASTERN NIGERIA.
}

(Received 7, December 2011; Revision Accepted 30, February 2012)

\begin{abstract}
Wetland soils developed on limestone parent materials were characterized and classified. In the study, eight (8) profile pits were sunk in 3 sites within Cross River State in 2006, described and sampled according to FAO (1988) guidelines. The samples were analysed in the laboratory using routine methods. Results obtained for morphological studies and physicochemical analysis showed that the soils were generally deep to shallow, moderately well drained to poorly-drained with weak red to light grey, Dark reddish brown to reddish brown, yellowish brown in colour. The soils are weak, medium, and crumb, moderate and sub-angular blocky structure. The texture ranged from sandy loam, silt, loam, loamy sand, sandy clay and clay loam. Bulk density values ranged between $1.20 \mathrm{~g} / \mathrm{cm}^{3}$ and $1.85 \mathrm{~g} / \mathrm{cm}^{3}$ with a mean of $1.37 \mathrm{~g} / \mathrm{cm}^{3}$. Particle density values ranged from $2.18 \mathrm{~g} / \mathrm{cm}^{3}$ to $3.70 \mathrm{~g} / \mathrm{cm}^{3}$ with a mean of $2.74 \mathrm{~g} / \mathrm{cm}^{3}$. The soils showed total porosity of $50 \%$ on the average which indicated good soils for maximum plant growth. The soils are slightly alkaline to moderate alkaline in reaction. Organic matter, total nitrogen, Available phosphorus contents, calcium, magnesium, potassium, and sodium contents were rated as low to moderate. An effective cation exchange capacity value of $10.36 \mathrm{cmol} / \mathrm{kg}$ was rated moderate with base saturation values above 82 per cent for these soils. The soils were classified as Inceptisols and Alfisols.
\end{abstract}

KEYWORDS: Wetland Soil, Limestone Parent-Material, Morphological Characteristics.

\section{INTRODUCTION}

Wetland soils are hydromorphic, which is characterized by an excess of soil water at least for a short period of time (Ibanga et al., 2005). The soil processes, which operate under such conditions are called gleying and ferrolysis and these are induced by water saturation if organic matter and soil temperature allow microbial activity. These soils have gleying horizons, and pseudogley horizons, where mottles and concentrations of re-oxidized compound occur. These gley or pseudogley horizons are found either near the surface or at depth depending on the fluctuating water table regime. (Ibanga et al, 2001). Limestones are sedimentary rocks composed mainly on carbonates, which are always in the form of aragonite, calcite and dolomite, plus small amounts of iron bearing carbonates (Peltijohn, 1975). Consolidated products of calcareous sands, limy mud and crushed shells also constitute limestone. (Anatoles, 1996). Soils derived from limestones are calcimorphic in nature being formed from calcareous parent materials on upland and slope (Bridges, 1970). Limestone deposits in Cross River State are found in Akamkpa, Biase, Odukpani and Yakurr Local Government Areas. These include impure limestone such as Marls found at new Netim and pure one found at Mfamosing. It fringes the sand stones known as "Awi formation" which again fringes the basement complex. They are found concentrated at the Southern part of Cross River State at boundary between the Calabar flank and the Precambrian Oban Massif (Akpan, 1990). These formations represent one of the oldest and major known marine carbonate sequences.
They are cenomanian to mid-albian in age (Peter, 1982). Limestones are the cheapest ingredient used for agricultural liming purpose and also wetland soils support any vegetation that tolerates permanent or periodic wetness like rice, banana, Plantain, sugar cane, cocoyam, yam, early maize and vegetables production.

In Nigeria good agricultural lands are being appropriated for urban, infrastructural or industrial uses and degraded crop lands are being abandoned while other lands are being opened up for farming, often at the expense of forests. In yet other cases, marginal lands are subjected to intensive cropping. According to Southcenter (1997), expansion of the cultivated area should continue to play a significant role in providing increased food supplies; and Cross River State should be a part of this global move. The objectives of this study was to characterized wetland soils developed on lime stones parent material by morphologically, physico-chemically and also, to make recommendations for their better utilization.

\section{Materials and Methods \\ Cross River State lies between latitudes $4^{\circ} 27^{\prime}$} and $6^{\circ} 45^{\prime}$ North and longitudes $7^{\circ} 15$ and ${ }^{\circ} 28^{\prime}$ ' East. The climate of Cross River State is equatorial, characterized by a long wet season lasting from March to July with heavy down pours, strong wind storm, violent thunder and lightening; a short dry season known as the "August Break" usually in July or August; a short wet season between September and November to early March and climaxes between December and January during the hamattan (Dry dusty weather). (Afangide et al., 2010). 
There is uniformity of temperature ranges between $21^{\circ}$ $32^{\circ} \mathrm{C}$ (Nwajiuba and Oyeneke, 2010). Rainfall ranges between $1,300-3000 \mathrm{~mm}$ annually with relative humidity ranging from 75 to 85 percent (Okonkwo and Mbajiorgu, 2010).

The study was carried in the rainy season in 2006. Three (3) limestone areas are selected for the study, viz: Mfamosing, New Netim (Odukpani) and Abini. SThree (3) profile pits with dimension of $2.0 \times 1.5 \times 1.5$ $\mathrm{m}$ were sank, each in a soil pedon. The pedons were in Odukpani (DU), Mfamosing (MF), and Abini (AB) all in southern Cross River State. The depths of each soil profile was dictated by the presence of perched water table up to $90 \mathrm{~cm}$. Description and sampling were done according to the (Soil Survey Staff, 2002) guidelines. The free soil survey method of Esu (2010) was used. A total of eight (8) samples were collected from the three pedons. Soil morphological features described were colour, texture, structure, consistence, included materials and horizon boundary. Site environmental features were also recorded at each profile site Fig. 1. Samples were collected from the profile pits using hand trowels and spade employing the bottom-to-top approach. Soil samples collected from the profile pits were air-dried crushed and passed through a $2 \mathrm{~mm}$ sized sieve and stored in polythene bags for the physicochemical analysis. Particle size distributions were determined by the hydrometer method using sodium hexametaphosphate (calgon) as a dispersant (Soil Survey Staff, 2002). Bulk density was determined by collecting undisturbed core samples from each identified horizon using metal cores, these was later oven-dried at $105^{\circ} \mathrm{C}$ to a constant weight and the bulk density calculated as described by USDA-NRCS (Soil Survey Staff, 2006). Particle density was determined as described using pycnometer by (Bowles, 1992). Total porosity was determined mathematically from the result of bulk and particle density (Agbede, 2009) using this formula.

$$
\text { Porosity }=1-\left(\frac{\text { bulkdensity }}{\text { particledensity }}\right) x 100 \%
$$

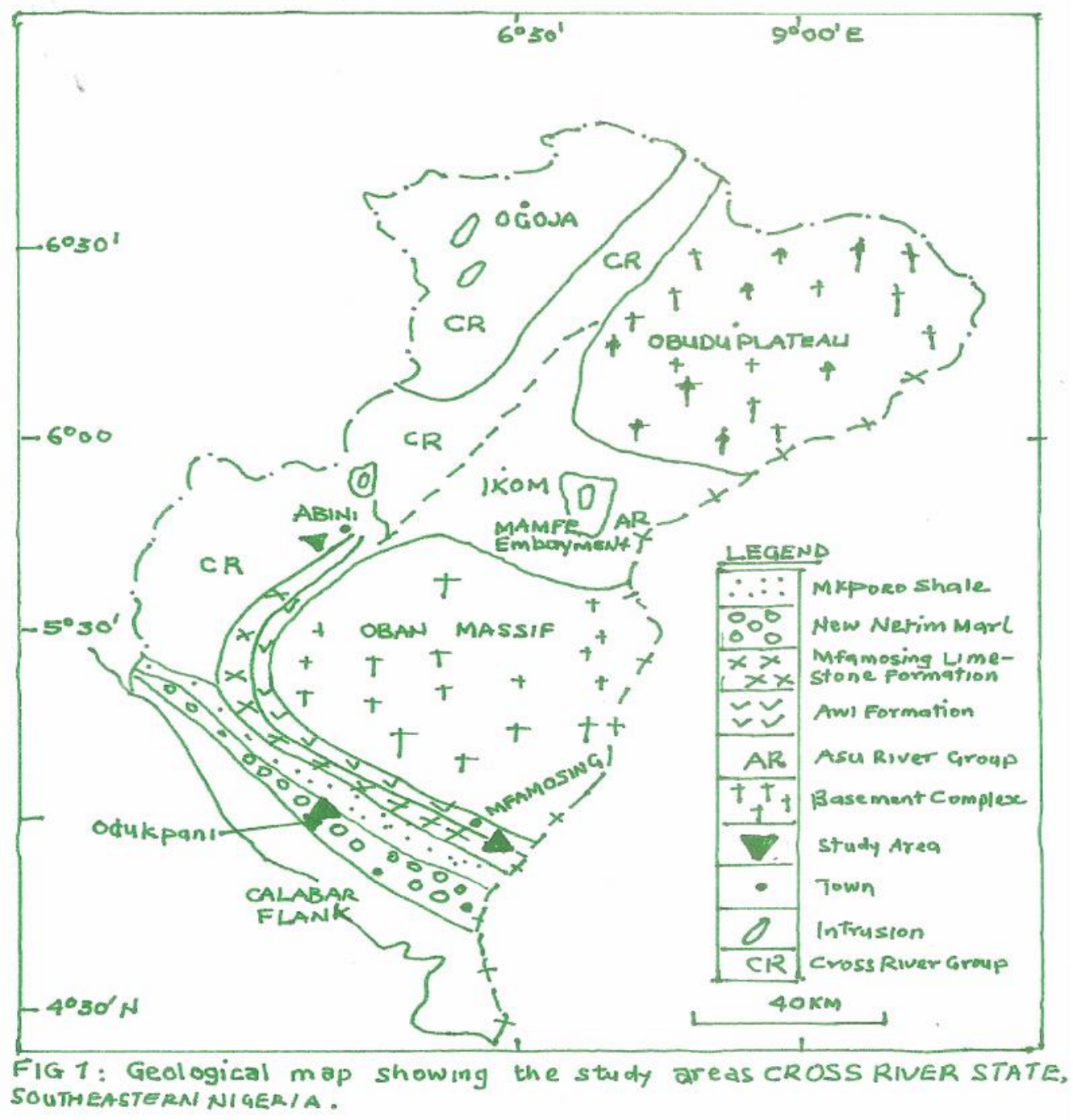


Soil $\mathrm{pH}$ was determined in 1:2 soils: water suspension ratio using a glass electrode $\mathrm{pH}$ meter (Thomas, 1996). Organic carbon was determined by wet combustion method of Walkley and Black as outlined by (Agbede, 2009). Organic mater determination was by multiplying the value of organic carbon by a factor of 1.724, a constant used for tropical soils (Agbede, 2009). Total nitrogen was determined on a sample sieved through $0.5 \mathrm{~mm}$ mesh using the Macro Kjeldahl method (Isirimah et al., 2003). Available phosphorus was extracted by the Bray No. 1 method (Bray and Kurtz, 1945) and $P$ in the soil solution determined calorimetrically by the ascorbic acid method as described by (Agbede, 2009). Exchangeable Acidity:

\section{RESULT AND DISCUSSION}

Morphological characteristics of the soils were described in description sheets. Soils were deep, shallow and poorly drained with colour range from weak red (2.5YR 4/2), orange (2.5YR $7 / 6)$ and light grey (7.5YR 8/2) with grey (10YR 6/1) mottle for soil units DU. Dark reddish brown, (5YR 3/3) and light grey (7.5YR 8/2) for soil unit MF. Yellow (10YR 8/6) and yellowish brown (10Yr 5/8) for soil unit $A B$. The light grey (10YR 6/1) hydromophic mottles indicates the fluctuating ground water table position during the wet period of the year (Table 1), the soils are sandy loam to loamy sand in texture for surface and subsurface with weak, medium crumb, sub angular blocky structure. Moist and wet consistence was firm to very firm, sticky, very sticky and plastic to very plastic. Many fire and medium roots were observed (Table 1). These properties enhance maximum roots penetration (Esu, 2010). The mechanical analyses results of the soils indicated that they are coarse-texture (Table 2). The textural classes were sandy loam to loamy sand for both surface and subsurface. The coarse nature of these soils could be attributed to the coarse nature of their parent materials (Ibanga et al., 2005) Bulk density values of these soils vary between 1.21 to $1.62 \mathrm{~g} / \mathrm{cm}^{3}$ with a mean of $1.37 \mathrm{~g} / \mathrm{cm}^{3}$ for both surface and subsurface which is ideal for agronomy practice, as it is less than the critical value of $1.45 \mathrm{~g} / \mathrm{cm}^{3}$. This is confirmed by Essoka (2000) who found that states bulk density less than $1.8 \mathrm{~g} / \mathrm{cm}^{3}$ will not impede root penetration (Table 2). Particle density of these soils range from $2.42 \mathrm{~g} / \mathrm{cm}^{3}$ to $3.10 \mathrm{~g} / \mathrm{cm}^{3}$ with mean of 2.74 $\mathrm{g} / \mathrm{cm}^{3}$ for surface and subsurface which rated too high and greater than the critical value of $2.60 \mathrm{~g} / \mathrm{cm}^{3}$ for
$\mathrm{Al}^{3+}$ and $\mathrm{H}^{+}$were determined by leaching the soil with $1 \mathrm{~N}$ $\mathrm{KCl}$ solution and the extract titrated with standard $\mathrm{NaOH}$ solution (Udo et al., 2009). Exchangeable cations (Ca, $\mathrm{Mg}, \mathrm{K}$ and $\mathrm{Na}$ ) were leached from the soil sample using $1 \mathrm{~N} \mathrm{NH} 4$ OAc (pH 7.0) buffer. The $\mathrm{Na}$ and $\mathrm{K}$ were measured with a flame photometer while the $\mathrm{Ca}$ and $\mathrm{Mg}$ were determined by EDTA titration as outlined by (Esu, 2010). Effective cation exchange capacity (ECEC) of the sample was determined by summing up the exchangeable cations plus exchangeable acidity. Percentage base saturation was obtained by expressing the sum of exchangeable cations as a percentage of the effective cation exchange capacity (IITA, 2000), using the formula:

$$
B S \%=\frac{\sum(C a+M g+K+N a)}{E C E C} \times 100
$$

tropical mineral soils (Essoka and Esu, 2001). Total porosity values showed range between 49.80 and 50.00 $\%$ and tended to decreased with increase in profile depth (Table 2).

The result of chemical properties in (Table 3) shows pH values of 7.81 to 8.20 with a mean of 7.97 for surface and subsurface soils. This is rated as slightly alkaline to moderately alkaline in reaction (Esu, et al., 2009). The organic matter, total nitrogen, available phosphorus of the soils varied between $2.38-0.83 \%$, $0.04-0.10 \%$ and $13.00-1.08 \mathrm{mg} / \mathrm{kg}$ respectively for surface and subsurface soils. The values were rated low to very low for organic mater; very low to low for total nitrogen and medium to low for available phosphorus. Available phosphorous generally increased with depth while $\mathrm{N}$ and organic carbon decreased with soil depth. The mean exchangeable $\mathrm{Ca}, \mathrm{Mg}, \mathrm{K}$, and $\mathrm{Na}$ contents for these soils were $7.38,1.61,0.66$, and $0.11 \mathrm{cmol} / \mathrm{kg}$ respectively, and were rated low to moderate apart from $\mathrm{Ca}$ as shown in Table 3. However, Ca was high as the soil had limestone basement principally. Also percentage base saturation of $82.38 \%$ was rated as high for these soils.

Soil classification (Table 4) was done using USDA Soils Taxonomy (soils survey staff (2003) and with approximate correlation in FAO (1988) UNESCO soil map of the world legend FAO (1988). The soils of the study areas were mainly Inceptisols and Alfisols while MF and $A B$ met the Inceptisols. All the soils were formed under humid and continually warm environment and have aquic moisture regime for $\mathrm{Du}$ and MF, Udic moisture regime for $A B$. 
Table 1: Morphological characteristics of the soils

\begin{tabular}{|c|c|c|c|c|c|c|c|c|}
\hline PEDON & $\begin{array}{l}\text { DEPTH } \\
\text { CM }\end{array}$ & $\begin{array}{l}\text { MUNSEL } \\
\text { COLOUR } \\
\text { (MOIST) }\end{array}$ & TEXTURE & STRUCTURE & CONSISTENCE & ROOTLET & BOUNDARY & INCLUSION \\
\hline DU & \multicolumn{8}{|c|}{ Valley bottom soils, Poorly drained $0-2 \%$ slope } \\
\hline AP & $0-13$ & $2.5 y r 4 / 2$ & Sandy loam & $\begin{array}{l}\text { Week, medium, } \\
\text { SBK }\end{array}$ & & $\begin{array}{l}\text { Many, } \\
\text { medium }\end{array}$ & Clear, weary & \\
\hline$A B$ & $13-40$ & $2.5 \mathrm{YR} 7 / 6$ & Sandy clay loam & $\begin{array}{l}\text { Week, medium, } \\
\text { SBK }\end{array}$ & $\begin{array}{l}\text { Very firm, slight sticky, slightly } \\
\text { plastic }\end{array}$ & $\begin{array}{l}\text { Many, } \\
\text { medium }\end{array}$ & Clear, weary & \\
\hline MF & \multicolumn{8}{|c|}{ Valley bottom soils poorly drained $0-2 \%$ slope } \\
\hline AP & $0-9$ & $2.5 Y R 4 / 2$ & Sandy loam & Week, medium & $\begin{array}{l}\text { Firm slightly sticky, slightly } \\
\text { plastic }\end{array}$ & $\begin{array}{l}\text { Many, } \\
\text { medium }\end{array}$ & Clear, weary & \\
\hline $\mathrm{AB}$ & $9-39$ & 7.5YR 5/6 & Sandy clay loam & $\begin{array}{l}\text { Moderate, } \\
\text { medium, SBK }\end{array}$ & Firm, very sticky, very plastic & Few, fine & $\begin{array}{l}\text { Gradual, } \\
\text { weary }\end{array}$ & \\
\hline$A B$ & \multicolumn{8}{|c|}{ Valley bottom soils poorly drained $0-2 \%$ slope } \\
\hline AP & $0-21$ & 10YR 8/6 & Sandy clay & $\begin{array}{l}\text { Weak, medium, } \\
\text { crumb }\end{array}$ & Firm, sticky, plastic & Few, medium & Clear, weary & \\
\hline$A B$ & $21-52$ & 10YR 5/8 & Clay loam & $\begin{array}{l}\text { Moderate, } \\
\text { medium, SBK }\end{array}$ & Firm, sticky, plastic & Few, fire & - & \\
\hline & \multicolumn{3}{|c|}{ * SBK - Sub Angular Blocky } & & & & & \\
\hline
\end{tabular}


Table 2: Physical characteristic of the soils.

\begin{tabular}{|c|c|c|c|c|c|c|c|c|c|}
\hline PEDON & Horizon & Depth cm & $\begin{array}{l}\text { Bulk density } \\
\mathrm{g} / \mathrm{cm}^{3}\end{array}$ & $\begin{array}{l}\text { Particle } \\
\text { density } \\
\mathrm{g} / \mathrm{cm}^{3}\end{array}$ & $\begin{array}{l}\text { Porosity } \\
\%\end{array}$ & $\begin{array}{l}\text { Clay } \\
\%\end{array}$ & $\begin{array}{l}\text { Silt } \\
\%\end{array}$ & $\begin{array}{l}\text { Sand } \\
\%\end{array}$ & $\begin{array}{l}\text { texture } \\
\text { Sandy loam }\end{array}$ \\
\hline \multirow[t]{3}{*}{ DU } & $\mathrm{AP}$ & $0-13$ & 1.21 & 2.42 & 50.00 & 4 & 28.70 & 67.30 & \\
\hline & $A B$ & $13-40$ & 1.33 & 2.66 & 50.00 & 11 & 24.70 & 64.30 & Sandy loam \\
\hline & $\begin{array}{l}\mathrm{Bt} \\
\text { Mean }\end{array}$ & $40-60$ & $\begin{array}{l}* \\
\mathrm{ND} \\
1.27\end{array}$ & $\begin{array}{l}* \\
\text { ND } \\
2.54\end{array}$ & $\begin{array}{l}* \\
\text { ND } \\
50.00\end{array}$ & $\begin{array}{l}11 \\
8.66\end{array}$ & $\begin{array}{l}25.70 \\
26.33\end{array}$ & $\begin{array}{l}63.30 \\
64.63\end{array}$ & Sandy loam \\
\hline \multirow[t]{4}{*}{ MF } & $\mathrm{AP}$ & $0-9$ & 1.33 & 2.68 & 50.30 & 3.00 & 23.70 & 73.30 & Sandy loam \\
\hline & $A B$ & $9-39$ & 1.45 & 2.90 & 50.00 & 19.00 & 21.70 & 59.30 & Sandy loam \\
\hline & $\begin{array}{l}\mathrm{Bt} \\
\text { Mean }\end{array}$ & $39-90$ & $\begin{array}{l}\text { ND } \\
1.39\end{array}$ & $\begin{array}{l}* \\
\text { ND } \\
2.78\end{array}$ & $\begin{array}{l}* \\
\text { ND } \\
50.00\end{array}$ & $\begin{array}{l}41.00 \\
21.00\end{array}$ & $\begin{array}{l}13.70 \\
19.70\end{array}$ & $\begin{array}{l}45.30 \\
59.30\end{array}$ & Clay loam \\
\hline & $\mathrm{AP}$ & 0.21 & 1.33 & 2.66 & 50.00 & 49.80 & 15.50 & 38.00 & Sandy loam \\
\hline \multicolumn{10}{|l|}{$A B$} \\
\hline & $A B$ & $21-52$ & 1.55 & 3.10 & 50.00 & 45.10 & 14.80 & 45.80 & Sandy loam \\
\hline & Mean & & 1.44 & 2.88 & 50.00 & 47.45 & 19.70 & 41.90 & \\
\hline & $\begin{array}{l}\text { Grand } \\
\text { Mean } \\
{ }^{*} N D-N\end{array}$ & etermined & 1.37 & 2.74 & 50.05 & 22.99 & 21.06 & 57.08 & \\
\hline
\end{tabular}


Table 3: Chemical characteristics of the soils

\begin{tabular}{|c|c|c|c|c|c|c|c|c|c|c|c|c|c|c|c|}
\hline Pedon & Horizon & $\begin{array}{l}\text { Depth } \\
\text { (cm) } \\
0-13\end{array}$ & 7.81 & $\begin{array}{l}\text { Org } \\
\mathbf{C} \\
\% \\
1.26\end{array}$ & $\begin{array}{l}\text { Org M } \\
\% \\
2.17\end{array}$ & $\begin{array}{l}\text { TN } \\
\% \\
0.10\end{array}$ & $\begin{array}{l}\text { Av P } \\
\text { mg/Kg } \\
8.37\end{array}$ & $\begin{array}{l}\mathrm{Ca} \\
(\mathrm{cmol} / \mathrm{Kg}) \\
8.00\end{array}$ & 0.40 & 0.12 & 0.08 & $\begin{array}{l}\text { EA } \\
\text { cmol/kg } \\
1.88\end{array}$ & $\begin{array}{l}\text { CEC } \\
\text { cmol/kg } \\
8.50\end{array}$ & $\begin{array}{l}\text { ECEC } \\
\text { cmol/kg } \\
10.48\end{array}$ & $\begin{array}{l}\text { BS } \\
\% \\
82.0\end{array}$ \\
\hline \multirow{3}{*}{ DU } & $A B$ & $13-40$ & 8.02 & 0.68 & 1.17 & 0.06 & 4. 38 & 7.80 & 0.80 & 0.11 & 0.09 & 2.08 & 8.80 & 10.88 & 81.0 \\
\hline & $\mathrm{Bt}$ & $40-60$ & 8.04 & 0.88 & 1.52 & 0.01 & 13.00 & 7.40 & 0.40 & 0.12 & 0.10 & 1.04 & 8.02 & 9.06 & 89.0 \\
\hline & Mean & & 7.98 & 0.94 & 1.62 & 0.57 & 5.25 & 7.73 & 0.53 & 0.12 & 0.90 & 1.67 & 8.44 & 10.16 & 84.0 \\
\hline \multirow[t]{4}{*}{ MF } & AP & $0-9$ & 8.00 & 0.90 & 1.55 & 0.07 & 2.37 & 8.40 & 0.60 & 0.12 & 0.09 & 2.0 & 9.21 & 11.21 & 82.0 \\
\hline & $A B$ & $9-39$ & 7.99 & 0.39 & 0.67 & 0.07 & 2.87 & 6.60 & 6.60 & 0.11 & 0.08 & 2.51 & 7.39 & 9.95 & 74.0 \\
\hline & $\mathrm{Bt}$ & $39-90$ & 7.87 & 0.28 & 0.48 & 0.02 & 1.25 & 10.60 & 0.80 & 0.11 & 0.09 & 2.0 & 11.6 & 13.6 & 85.0 \\
\hline & Mean & & 7.95 & 0.53 & 0.90 & 0.53 & 2.16 & 7.80 & 2.67 & 0.11 & 0.80 & 2.17 & 9.36 & 11.55 & 83.3 \\
\hline \multirow[t]{4}{*}{$A B$} & AP & $0-21$ & 8.06 & 1.31 & 2.26 & 0.08 & 2.02 & 5.20 & 1.50 & 04.2 & 0.18 & 1.92 & 7.30 & 9.22 & 79.0 \\
\hline & $A B$ & $21-52$ & 7.99 & 0.75 & 1.29 & 0.08 & 1.08 & 5.00 & 1.80 & 0.38 & 0.19 & 1.08 & 7.38 & 8.45 & 87.0 \\
\hline & Mean & & 8.03 & 1.03 & 1.78 & 0.08 & 1.55 & 5.10 & 1.10 & 0.40 & 1.00 & 1.50 & 7.34 & 8.34 & 81.0 \\
\hline & $\begin{array}{l}\text { Grand } \\
\text { Mean }\end{array}$ & & 7.97 & 0.81 & 1.39 & 0.06 & 4.42 & 7.38 & 1.61 & 0.66 & 0.11 & 1.81 & 8.53 & 10.36 & 82.38 \\
\hline
\end{tabular}

Table 4: Soil taxonomic classification

\begin{tabular}{|l|l|l|}
\hline SOIL UNITS & USDA SOIL TAXONOMY & FAO/UNESCO SOIL LEGEND \\
\hline DU (Odukpani Pedon) & Aeric Endoaqualfs & Eutric Gleysols \\
\hline MF (Mfamosing Pedon) & Typic Dyustradepts & Plinthic Acrisols \\
\hline AB (Abini Pedon) & Typic Dyustradepts & Dystric Cambisols \\
\hline
\end{tabular}




\section{CONCLUSION AND RECOMMENDATIONS}

The present study of soils developed from limestone parent material in Cross River State, southeastern Nigeria indicates that their morphological and physico-chemical characteristics strongly reflect the nature of the environment in which the soils are formed. The low to moderate fertility status of the soils are reflective of the parent material and hydromorphic nature of the soils environment, which increases the reactions (alkalinity) of the soils and also inhibit some plant nutrients availability. Due to low fertility status of these soils, farmers should adopt a fertilization programme to improve on the fertility status of the soils for intensive crop production. Crop residues should also be incorporated in to the soils during tillage operation to conserve and improve on the organic matter status of the soils.

\section{REFERENCES}

Afangideh, A. I., Francis E. O. and Eja, E. I., 2010. A preliminary investigation into the annual rainfall trend and pattern for selected towns in parts of south-eastern Nigeria. Journal of Sustainable Development, 3 (3): 275-282.

Agbede O. O., 2009. Understanding soil and plant Nutrition. Salman press and co. Nig. Ltd. Keffi. $1-260$.

Akpan, E. B., 1990. Trace fossils and the depositional environments of the Mfamosing limestone, Calabar flank, South Eastern Nigeria. In. C. O. Ofoegbu (ed). The Benue Trough, structure and evolution friedr. Viewg and Sohn, Braunschweig, 360 .

Anatoles, D., 1996. Physical Geology. Cambridge University Press.

Bowles, J. E., 1992. Engineering properties of soils and their measurement $4^{\text {th }}$ ed, Boston: McGraw Hills.

Bray, R. H. and Kurtz, L. T., 1945. Determination of total and available forms of phosphorus in soils. Journal of Soil Science 53:39-45.

Bridges, E. M., 1970. World Soils. Cambridge University Press, Cambridge.

Essoka, A. N., 2000. Pedological Evaluation of some Inland Valley Central Soils of Cross River State Nigeria. M.Sc. Thesis (unpublished) to Dept. of Soil Sc. UNICAL.

Essoka, A. N. and I. E. Esu., 2001. Physical properties of inland valley soils of central Cross River State Nigeria. In: Management of wetland soils for substantable agriculture and environment proceedings $27^{\text {th }}$ annual conference of SSSN in Unical. 119-123.
Esu, I. E., 2010. Soil characterization, Classification and Survey. Heinneman Educational Book publishers, Nigeria. 232.

Esu, I. E., Akpan-Idiok A. U. G. A. Ayolagha and M. Idoko., 2009. Soil fertility evaluation in three Southern State (Cross River, Edo and Rivers). Consultancy report submitted to the FMAWR Abuja. 149.

F. A. O., 1988. F.A.O.-UNESCO soil map of the world reversed legend world soil resources. Rep. F.A.O.-Rome 60, 119.

Ibanga, I. J. and Nsokpo, E., 2001. Fertility Status of selected hydromorphic Soils in Akamkpa LGA, Cross River State. In: Management of wetland soils for sustainable agriculture and environment proceedings of the $27^{\text {th }}$ annual conference of the soil science society of Nigeria. 162-163.

Ibanga, I. J., Udoma, G. H., Edet, A. B. and Akpan F. S., 2005. Physico- chemical properties of some limestone soils in southeastern Nigeria. Nigerian Journal of soil science 15:81-85.

IITA., 2000. Selected method for soil and plant analysis manual series No. 1 Ibadan International Institute of Tropical Agriculture (IITA).

Isirimah, N. O; A. A. Dickson and C. Igwe., 2003. Introdcutory soil chemistry and Biology for Agriculture and Biotechnology. Osia Int'l Publishers Ltd. Nig. 270.

Nwajiuba, C and Oyeneke, R., 2010. Effects of climate on the agriculture of sub-Saharan Africa: Lessons from Southeast Rainforest Zone of Nigeria Oxford Business and Economic Conference programme, June 28-29. 1-18.

Okonkwo, G. I. and C. C. Mbajiorgu., 2010. Rainfall intensity Duration frequency analysis for South Eastern Nigeria. Agricultural engineering international: The CIGR Electronic Journal. Manuscript 1304. vol. 12: 1-15.

Petters, S. W., 1982. Central West African Cretaceous Tertiary Benthic criminifera and stratigraphic paleography. America petroleum Geology Bulletin, 179: 104-113.

Pettijohn, F. G., 1975. Sedimentary Rocks, $2^{\text {nd }}$ edition New York: Haspel and Brossi Bridges, E. M. (1970) World Soils. Cambridge. Cambridge University press.

Soil survey staff, 2002. Field book for describing and sampling soils. Version 2.0 National soil survey center, natural resources conservation service, USDA Lincoln Nebraska, 1:9-13. 
Soil survey staff, 2003. Key to soil taxonomy, revised edition $\left(9^{\text {th }}\right)$ Washington D. C. USDA soil conservation service.

Soil Survey Staff, 2006. Soil survey Manual. US Depts Agric Handbook 18, US. Govt. Printing Office, Washington.
Thomas, G. W., 1996. Exchangeable cations in A.L. Pages R. N. Miller and D. R. Keeney (Eds) method of soil analysis part 2. $2^{\text {nd }}$ edition. ASA Madison. 159-164.

Udo, E.J.; T. O. Ogunwale; A. O. Ano and I. E. Esu., 2009. Manual of soil, plant and water analysis. Sibon Books Publishers Ltd., Nigeria 